\title{
DESCRIPTION OF MIDWIFERY STUDENT KNOWLEDGE ABOUT 1000 HARI PERTAMA KEHIDUPAN (HPK) BASED ON MEDIA INSTITUTE OF HEALTH SCIENCES KUNINGAN 2020
}

\author{
${ }^{1}$ Evi Soviyati, ${ }^{2}$ Toto Sutarto Gani Utari, ${ }^{1}$ Tri Hardini \\ ${ }^{1}$ STIKes Kuningan, ${ }^{2}$ Universitas Pasundan Bandung \\ eviesofia73@gmail.com
}

\begin{abstract}
The first 1000 days of life or 1000 Hari Pertama Kehidupan (HPK) is a period starting from the beginning of pregnancy until the baby is 2 years old. Knowledge of 1000 HPK is very important for midwifery students as a benchmark for health workers in serving clients in the future. About 6 in 10 students still do not understand and know about the First 1000 Days of Life. The purpose of this study was to describe the level of knowledge of midwifery students about the first 1000 days of life based on media sources at the Kuningan College of Health in 2020. Descriptive research method with observational design, population of midwifery students of level II as many as 40 people, using a total sampling technique. Direct data collection (primary data) using a questionnaire. Data analysis using univariate analysis. The results showed that most midwifery students level II had less knowledge of 20 respondents $(50 \%)$, most of the media sources for obtaining information about HPK were mostly audio-visual 32 (80\%), and the level of knowledge of midwifery students level II about 1000 HPK based on media sources. as many as 17 (42.5\%) had less knowledge. It is recommended that level II midwifery students get information about $1000 \mathrm{HPK}$ not only through the media but can seek information from various sources, for the Midwifery Study Program to be used as evaluation material, as input for developing an additional curriculum related to 1000 HPK in the Midwifery Care course so that it can increase student knowledge.
\end{abstract}

Keywords: HPK ; Knowledge; Midwifery Students; Media Resources.

\section{Introduction}

The First 1000 Days of Life or 1000

Hari Pertama Kehidupan (HPK) is an event where a mother begins to become pregnant for 9 months until her baby is 2 years old. This period is also called the golden age 
period because at this time the baby's growth has experienced very rapid growth and development and that period will never be repeated at any time. For this reason, to support the growth and development of these babies, it is necessary to fulfill needs such as nutrition, parenting, health checks and others. If the needs in 1000 HPK are not fulfilled, it will have an impact on the growth and development of the baby such as impaired brain development, intelligence, physical and mental development so that these disorders will affect their future.

Midwifery students as prospective midwives must understand and understand about 1000 HPK, because in the future, they will prepare women to become good prospective mothers. Thus, good student knowledge is needed to support this. The low level of knowledge of midwifery students will have an impact on the baby the mother will deliver. In addition, the impact felt by herself as a midwife is the stigma of society regarding her being incompetent in serving the community, especially women who will become prospective mothers so that the midwife will no longer be trusted by the community.
Print media and mass media are a means of obtaining various information needed by everyone, including information about 1000 HPK which can be used as knowledge by midwifery students. At this time there are many media sources available, even so we must remain selective in using these media sources so that the knowledge we seek can be accounted for.

According to (Rahayu, 2018), the 1000 HPK Movement is a movement to accelerate nutrition improvement adopted from the Scaling Up Nutrition (SUN) Movement. The SUN Movement is a global movement under the coordination of the UN Secretary General. The global goal of the SUN Movement is to reduce nutritional problems in $1000 \mathrm{HPK}$, from early pregnancy to 2 years of age states that the bad effects that can be caused by nutritional problems in the short term are disruption in brain development, intelligence, physical development disorders and metabolic disorders in the body, while in the long term the bad effects that can be caused are reduced cognitive abilities and learning achievement, decreased immunity so that you get sick easily, and a high risk for diabetes, obesity, heart disease and blood vessels, cancer, 
stroke, and disabilities in old age. All of this will reduce the quality of Indonesia's human resources, productivity and national competitiveness.

According to UNICEF, in (Patimah, 2017) states that the critical period is a period of rapid growth of the number or size of cells during which cells are prone to loss. The vulnerability occurs during a period of maximum growth speed. This is the maximum period which is the potential for determining the end of cell development.

According to the National Education Association (NEA) in (Riyanto, 2014) media are forms of printed and audiovisual communication and their equipment. The media should be manipulable, visible and readable. they state that learning resources are used in education and training in a system consisting of a set of materials or situations that are created on purpose and created to allow students to learn individually.

Research results from (Dattilo \& Saavedra, 2020) Healthy growth during the first 1,000 days, spanning from conception to age 24 months, represents a crucial period which influences the long-term physical and cognitive development of individuals, Considerations related to intervention design, behavior change strategies, and scale-up efforts are needed to improve the efficacy of nutrition education strategies in early nutrition.

Based on the results of the study, it can be concluded that there is an effect of nutrition education about 1000 HPK on the knowledge and nutritional attitudes of female students. The results of preliminary studies that have been carried out on students of the Diploma and Bachelor Midwifery study programs at Institute of Health dan Science Kuningan (STIKes Kuningan) from the first to the third level are obtained values that vary from the smallest to the largest score. The range of values obtained was from the value 5 to the value 8 . There were 10 questions asked of 10 students of various levels regarding the First 1000 Days of Life based on media sources. The percentage of students who get a score of 5 is $40 \%$, then those who get a score of 6 are $30 \%$ and 7 are $20 \%$ and who get the highest score of 8 is $10 \%$. That way the accumulated percentage of students who get a score of more than 5 is $60 \%$ and students who get a score of 5 are $40 \%$, but there are 2 students who get a score of more than 5 in a bad way by looking at the answer on the internet and 
asking other people. So, indirectly, the 2 students did not know about the first 1000 days of life, so the researcher was interested in conducting research with the title " Description Of Midwifery Student Knowledge About 1000 Hari Pertama Kehidupan (Hpk) Based On Media Institute Of Health Sciences Kuningan $2020 ”$

\section{Methods}

This type of research is a descriptive method. The research design used an observational design. The population in this study were students of midwifery level II because they had received courses on Midwifery Care as many as 40 students who were at the Institute of Health Sciences. The number of samples in this study were 40 student taken from midwifery students level II. The sampling technique in this total sampling.

The independent variable in this study is the source of the media used by midwifery students who are at Institute of Health, Kuningan. The dependent variable is the level of knowledge of midwifery students about 1000 HPK. Data collection that has been standard or data collection tools that have standards of validity and reliability. The instrument in this study was to use a questionnaire containing the knowledge of mid-level midwifery students and 1000 HPK to determine the knowledge of midwifery students level II about the first 1000 days of life based on media sources. This questionnaire uses the google form application.

\section{Result}

Table 1. Distribution of Frequency Levels of Knowledge and Media Source of Midwifery Students about 1000 HPK

\begin{tabular}{|c|c|c|}
\hline Knowledge & Frequency & Percentage $(\%)$ \\
\hline Well & 2 & 5 \\
\hline Enough & 18 & 45 \\
\hline Less & 20 & 50 \\
\hline Total & 40 & 100 \\
\hline Media sources & Frequency & Percentage (\%) \\
\hline Audio & 2 & 5 \\
\hline Visual & 6 & 15 \\
\hline Audio visual & 32 & 80 \\
\hline Total & 40 & 100 \\
\hline
\end{tabular}


Source : 2020 Research Result

The following is a table of frequency distribution of media sources for midwifery students level 2 as many as 20 respondents (50\%), knowledgeable enough as many as 18 respondents (45\%), and good knowledge as many as 2 respondents $(5 \%)$. And the results show that from 3 kinds of media sources, most of the respondents were audio-visual as In addition, here is a table of frequency distribution of the level of knowledge of midwifery students about the first 1000 days of life based on media sources many as 32 respondents $(80 \%)$, visual media were 6 respondents $(15 \%)$ and media sources form of audio were 6 respondents $(5 \%)$.

Table 2. Cross Tab Levels of Knowledge of Midwifery Students About 1000 HPK and Media Sources

\begin{tabular}{lcccccccc}
\hline \multirow{2}{*}{ Media Sources } & \multicolumn{9}{c}{ Knowledge } & \multicolumn{2}{c}{ Total } \\
\cline { 2 - 9 } & \multicolumn{2}{c}{ Well } & \multicolumn{2}{c}{ Enough } & \multicolumn{2}{c}{ Less } & \multicolumn{2}{c}{} \\
\cline { 2 - 9 } & F & $\%$ & F & $\%$ & F & $\%$ & F & $\%$ \\
\hline Audio & 0 & 0 & 0 & 0 & 2 & 5 & 2 & 5 \\
Visual & 0 & 0 & 5 & 12,5 & 1 & 2,5 & 6 & 15 \\
Audio Visual & 2 & 5 & 13 & 32,5 & 17 & 42,5 & 32 & 80 \\
\multicolumn{1}{c}{ Total } & 2 & 5 & 18 & 45 & 20 & 50 & 40 & 100 \\
\hline
\end{tabular}

Source: 2020 research results

Based on table 3 above, it can be seen that of the 40 respondents there are 20 respondents who have less knowledge of using media sources in the form of audio as many as 2 respondents (5\%), visual as many as 1 respondent $(2.5 \%)$ and the use of audio-visual by 17 respondents (42.5\%). Then of the 18 respondents who have sufficient knowledge, none of them use media sources in the form of audio $(0 \%)$, while the use of visual media is only $12.5 \%$ or only 5 respondents use it and for the use of audio visual there are $32.5 \%$ or there are 13 respondents who use it. Furthermore, for students who have good knowledge there are only 2 respondents with a percentage of $5 \%$ and 2 respondents only use media sources in the form of audio-visuals. 


\section{Discussion}

Based on the description of table 1, it is found that some of the level of knowledge of midwifery students about the first 1000 days of life is in the poor category $(50 \%)$ of the 40 respondents.

Based on the results of the study, this is due to the lack of interest of respondents in seeking and digging information on their own desires, lack of support, encouragement and motivation from people around the respondent towards the respondent's learning process, especially in studying 1000 HPK, respondents are more interested in something that makes he feels happier than looking for information about 1000 HPK such as playing on social media (whatsapp, Instagram, twitter, facebook and others), the lack of facilities and infrastructure owned by respondents such as quotas, networks, etc. so that respondents do not know about $1000 \mathrm{HPK}$, this results in a lack of student knowledge. Based on the description of table 2 , it can be concluded that the media sources of midwifery students about the first 1000 days of life mostly use media sources in the form of audio-visual $(80 \%)$ or there are 32 users (respondents) media sources from 40 respondents.
Based on the results of the research, this is because audio visual is one of the media sources that is easier to understand because audio visuals display video or recordings so that those who see it are easier to remember, it is more interesting to watch because in the audio visual there are images, videos as well as sound make respondents excited to see it, the process of capturing power is faster than other media sources because this audio visual consists of images and sounds that can be heard and seen. In addition, due to the increasingly sophisticated process of the times, this audio visual is easy to carry anywhere, to use anywhere, and anytime because it is already included in a gadget (handphone) whether it is connected to an internet connection or not.

This study is in accordance with the results of research (Trisnawati et al., 2016) The results of this study are that most of the respondents' knowledge about nutrition in the first 1000 days of life is good, and most of the respondents' attitudes towards nutrition in the first 1000 days of life are supportive. However, after being tested there was no correlation between knowledge and attitudes of pregnant women towards nutrition in the first 1000 
days of lifenamely the fisher exact value was 0.589 .

This is in line with research from (Mardiana et al., 2020) Nutrition counseling is a learning process to develop understanding and positive attitudes towards nutrition so as to form and have good eating habits. The research aims to increase knowledge and attitudes as well as nutrition intake of pregnant women through the media drama of the first thousand days of life at the 11 Ilir Health Center in Palembang. Types of research Quasi-experimental with pretest posttest with control design. The results of the independent $\mathrm{t}$ test statistic test found a significant effect of 1000 HPK Drama Interventions on the average score of knowledge, attitude, intake of $\mathrm{E}, \mathrm{P}, \mathrm{KH}$, $\mathrm{Fe}$, and there was no effect of fat intake of respondents in both groups.

\section{Conclusion}

1. An overview of the level of knowledge of midwifery students about 1000 HPK at Institute of Health Kuningan, some of them fall into the low category, namely as many as 20 respondents with a percentage of $50 \%$.

2. Description of media sources for midwifery students about 1000 HPK at
Institute of Health Kuningan that almost all of them use media sources in the form of audio visuals by $80 \%$ or as many as 32 users (respondent). An overview of the level of knowledge of midwifery students about 1000 HPK on media sources at Institute of Health Sciences, Kuningan there were 20 respondents who were included in the category of lack of knowledge using media sources in the form of audio use by 2 respondents (5\%), visual 1 respondent $(2.5 \%)$ and audio visual use by 17 respondents $(42.5 \%)$.

\section{Suggestion}

1. Midwifery Students

It is hoped that students will be more active in finding out information about 1000 HPK either through the level of education that is currently being taken or from various media sources that are better and more relevant so that they can prepare mothers in the future starting from early pregnancy to the baby's age 2 years.

\section{STIKES Kuningan}

It is hoped that they can become one of the facilitators for students in supporting learning and digging deeper into information about the first 1000 days of life so that it can indirectly develop a curriculum, especially in the course of 
Maternity Care for Pregnancy, Childbirth,

Newborns, Infants, Toddlers and Pre

School children.

\section{Reference}

Journal:

Dattilo, A. M., \& Saavedra, J. M. (2020). Nutrition education: application of theory and strategies during the first 1,000 days for healthy growth. In Nutrition Education: Strategies for Improving Nutrition and Healthy Eating in Individuals and Communities (Vol. 92, pp. 1-18). Karger Publishers.

Mardiana, M., Yulianto, Y., Yuniarti, H., \& Susanto, E. (2020). Increased of Knowledge, Attitudes, and Nutrient Intake Pregnant Women Through a
Thousand Days First Life Media Drama. Jurnal Midpro, 12(1), 25-32.

Trisnawati, Y., Purwanti, S., \& Retnowati, M. (2016). Descriptive Study of Knowledge and Attitudes of Pregnant Women on Nutrition in the First 1000 Days of Life at Sokaraja Health Center, Banyumas Regency. Jurnal Kebidanan, 8(02).

\section{Text Book:}

Patimah, S. (2017). Nutrition for Young Women plus the First 1000 Days of Life. PT. Refika Aditama.

Rahayu, A. (2018). Nutrition of the First Thousand Days of Life. CV Mine.

Riyanto, B. (2014). Knowledge and Attitudes Questionnaire in Health Research. Salemba Medika. 